(C) The Author(s), 2019. Published by Cambridge University Press on behalf of The Hegel Society of Great Britain. This is an Open Access article, distributed under the terms of the Creative Commons Attribution-NonCommercial-ShareAlike licence (http:/ / creativecommons. org/licenses/by-nc-sa/4.0/), which permits non-commercial re-use, distribution, and reproduction in any medium, provided the same Creative Commons licence is included and the original work is properly cited. The written permission of Cambridge University Press must be obtained for commercial re-use.

\title{
Hegel's Reception of Aristotle's Theology
}

\section{Tobias Dangel}

\begin{abstract}
In several of his writings Hegel suggests an identification of his absolute idea/spirit with Aristotle's God in the Metaphysics. This suggestion is remarkable since it indicates that Hegel regarded his philosophy in line with classical positions in ancient metaphysics. Although there is increasing discussion of the relation between Hegel and Aristotle it is still doubtful what it was that Hegel seemed to find at the highest point of Aristotle's philosophy. To clarify this relation within the realm of first philosophy I will first give a short reconstruction of Aristotle's conception of God in order, second, to confront this conception with the absolute idea/spirit in Hegel. Against Ferrarin, I will not primarily discuss the conception of actuality/activity and infinite subjectivity; rather I will focus on Aristotle's and Hegel's ontological understanding of truth. The new thesis in my paper is that Hegel can relate his theory of the absolute idea/spirit to Aristotle's God on the basis of their shared understanding of truth. This understanding allows both of them to find the highest realization and thus the fulfillment of truth in the self-thinking thinking of God (Aristotle) or the self-thinking thinking of the absolute idea/spirit (Hegel). When Hegel seems to return to Aristotle at the end of his system, this return has its systematic link in the idea of a fulfilled truth which is God or the Absolute in the sense of self-thinking thinking. Although Hegel's return to Aristotle's theology has a certain plausibility, it is also limited by the fact that for Aristotle God's self-thinking thinking is not a process of selfdetermination, as Hegel finds it to be and which leads him to miss a crucial feature of Aristotle's theology.
\end{abstract}

It is no exaggeration to say that Hegel was one of the most influential of those who rediscovered Aristotle's philosophy in the early nineteenth century. In the second (1827) and the third (1830) editions of his Encyclopaedia of the Philosophical Sciences, he ends the Philosophy of Spirit, and thus the conclusive part of his mature system, with an untranslated and uncommented quotation that is taken from the seventh chapter of book $\Lambda$ in Aristotle's Metaphysics. In book $\Lambda$, as is well known, Aristotle formulates some of the most speculative sentences about God and the human 


\section{Tobias Dangel}

intellect which we can find in the entire corpus of ancient philosophy. There can be no doubt that these sentences left a lasting impression on Hegel.

In book $\Lambda$ Aristotle presents a great many positive determinations of God. These determinations include, for example: God is an unmoved mover

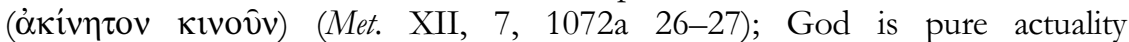

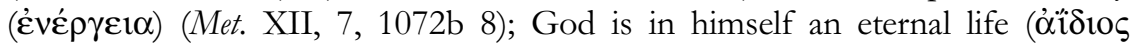
$\zeta \omega \eta$ ) (Met. XII, 7, 1072b 27-28); God as the first principle is a substance

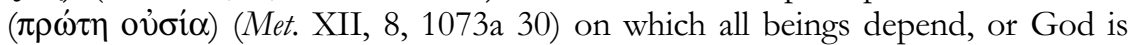
an active intellect (Met. XII, 7, 1072b 27). To this extent, then, it is Hegel himself who wants us to correlate his theory both of the absolute idea and absolute spirit to Aristotle's theology. There can be no doubt that Hegel regarded this reference as highly relevant to understanding the fundamental intention of his own philosophical system. ${ }^{1}$ I think he is clear about this when he says, in the Encyclopedia where he gives an exposition of the absolute idea: 'This unity is consequently the absolute and all truth, the Idea which thinks itself-and here at least as a thinking or Logical Idea' (EL: $\$ 236,292) .{ }^{2}$ And then he goes on in the addition to this paragraph: 'Hitherto we have had the idea in development through its various grades as

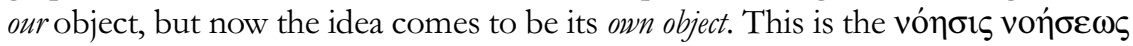
which Aristotle long ago termed the supreme form of the idea' (EL: $\$ 236 \mathrm{~A}, 292)$. In his confrontation with Aristotle's theology, Hegel recognizes a deep affinity between his conception of the absolute idea or the absolute spirit and Aristotle's conception of God who is as the first substance an intellect, the actuality of which consists in a thinking that is nothing other than the thinking of thinking. In the following, I will try to sketch out the basic outlines of Aristotle's conception of the divine intellect as well as of Hegel's conceptions of, respectively, absolute idea and absolute spirit, in order to give Hegel's connection to Aristotle's theology a contour. This contour allows us to better see similarities and differences between both approaches and how Hegel himself understood them. ${ }^{3}$

\section{The concept of God in Aristotle's theology}

In chapter 6-7 of book $\Lambda$ Aristotle develops a proof of the necessary existence of a first being or substance that as an eternal source of natural movement will guarantee that nature as a whole has no beginning and no ending in time. ${ }^{4}$ This first being is Aristotle's famous unmoved mover whose essence is pure actuality. Under the condition that there is such a being that is pure actuality according to Aristotle, there is also always change in nature-whether it is change in the sense of the coming to be or the passing away of substances, in the sense of alteration of accidental properties of substances, or in the sense of locomotion of substances. ${ }^{5}$ For Aristotle, nature as the whole of the sensible world has an existence without 


\section{Hegel and Aristotle's Theology}

beginning and ending in time if and only if there are always substances which move or change. This means, according to the Physics, if there are always beings which

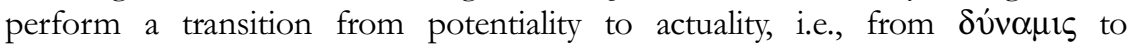

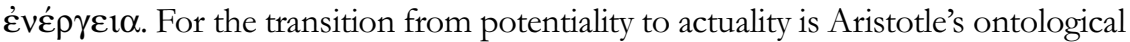
explanation of what movement or change is (Phys. III, 1, 201b 3-5). But if there is always movement or change, a first mover must be presupposed, so that the whole cosmos in regard to its actuality depends on such a principle (Met. XII, 7, 1072b 11-14). ${ }^{6}$ Otherwise the coming to be and passing away of substances, the alteration of their accidental properties as well as the locomotion of substances, would not be necessary but merely contingent.

The first mover can provide the guarantee of the actuality of beings within the cosmos and, hence, of the cosmos itself only under the condition that he is in himself free from potentiality so that he can never stop moving the subordinated sensible substances. And it this which Aristotle means when he says that the first mover is God as pure actuality or pure ह́vं́ $\rho \gamma \varepsilon \varepsilon \alpha$, while, for all other beings or substances which are not God, there is $\delta v i v \alpha \mu \iota$ and hence possibility. From this Aristotle infers in chapter 7 of book $\Lambda$ that when God's being is pure actuality there can be no change in God, so that God is a being or a substance that is not only eternal

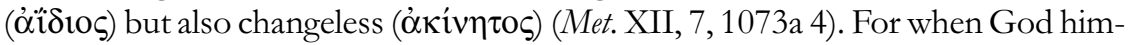
self is pure actuality, there can be no transition from potentiality to actuality in God. Thus, the first principle of the entire cosmos, contrary to all sensible substances that belong to the cosmos and have their position within the cosmological order, transcends the dimension of potentiality. As such, God as the eternal source of natural movement is not only unmoved or changeless but also a substance that is not sensible and does not belong to the cosmos.

In Aristotle's conception of the first mover God obviously has an existence that is quite similar to Plato's ideas, being transcendent substantial forms. Not being related to potentiality, Aristotle's first mover is not equipped with matter, so that the pure actuality of this substance must be thought of as pure form

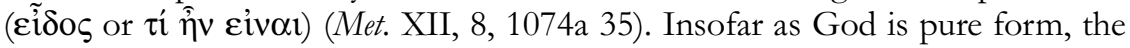
eternal source of cosmic movement is a substance that is intelligible or an intellect

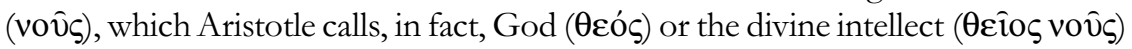
(Met. XII, 7, 1072b 14-30 and Met. XII, 9, 1074b 15-35). Being pure form, in the sense of being pure actuality, implies that in the divine intellect there can be no deficiency, since if there could be deficiency, it would be related to potentiality and matter, which would interfere with the fundamental ontological character of the first mover (see Lear 1988: 301). An intellect that is pure form and pure actuality and that as a necessary being cannot have its own principle of being in something else, then, must be an ontologically perfect being which exists independently of all

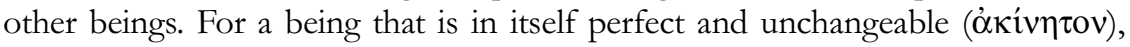
there is no chance of lacking anything or of privation $(\sigma \tau \eta \dot{\rho} \rho \varepsilon \sigma \iota)$. According to 


\section{Tobias Dangel}

Aristotle, such a perfect being, because of its own perfection, possesses the highest degree of ontological dignity, so that he regards God or the divine intellect as the

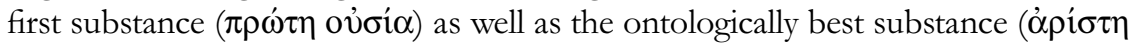

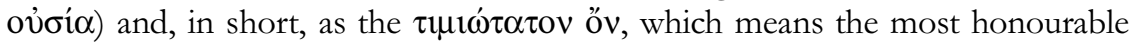
being (Met. XII, 9, 1074b 20 and Met. XII, 9, 1074b 26).

In as much as the divine intellect is an intellect, Aristotle raises the question in chapter 9 of book $\Lambda$ what it actually is that is thought by God, and whether God

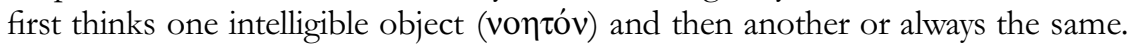
Aristotle argues that if God is pure actuality and therefore a perfect being which is changeless in itself, then it is impossible that God changes the intelligible object while he is thinking. This means, too, that the divine intellect is not so much an intellect in the sense of a faculty like the passive intellect (vov̂ऽ $\pi \alpha \theta \eta \tau$ เós) in the human soul, but it is an intellect that is eternally active. For this reason it is inaccurate to say that God is a vov $\varsigma$, for he is more correctly termed an eternal vónбrs, i.e., he is the intellect's eternal thinking. It is this eternal activity of the intellect which is the intellect's thinking which we actually mean when we speak of Aristotle's God or of the first mover. Due to being pure actuality, God cannot stop thinking just as he cannot change his object. But which object is it that God eternally thinks?

When we summarize what Aristotle says in chapter 7 and 9 of book $\Lambda$ about God's thinking, the best interpretation is that God does not think a plurality of dif-

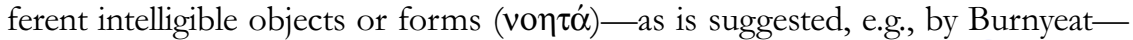
but rather thinks exactly one object and this object is God himself. ${ }^{7}$ In other words: The divine intellect thinks the divine intellect and that means that it is the divine intellect's thinking which is the one and only object of God's thinking. Aristotle's argument for this assertion is that God's thinking cannot think an intelligible object inferior to him, for otherwise this would contradict God's ontological dignity and perfection. For every intelligible object that is different from God must be inferior to him so that for the sake of his own perfection God's thinking can only be the thinking of himself. And since God is not only pure actuality, but the pure actuality of the intellect, God when he is the object of his own thinking must be the thinking of thinking. ${ }^{8}$ This is why Aristotle concludes in chapter 9 of book $\Lambda$ of the Metaphysics that God's thinking can be nothing else other than

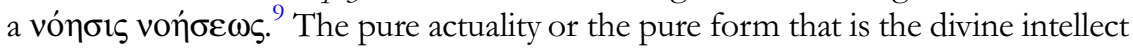
must be understood as a being or substance which is, in its own actuality, i.e., in the activity of its thinking, strictly self-related, so that God's existence is a thinking in

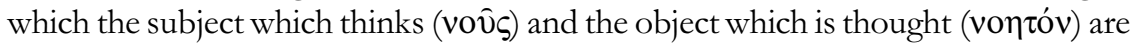
identical. God is the subject as well as the object of thought and this identity is articulated as the self-relation of the thinking of the divine intellect. God is a substance which exists not only as pure form, but as a form which is a self-related thinking and which is thus the highest realization of the identity of subject and 


\section{Hegel and Aristotle's Theology}

object-a realization which can take place only in the intellect's thinking and which

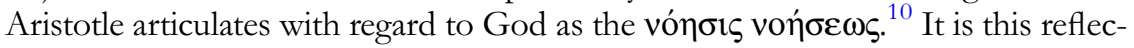
tion on a first principle of being in the Metaphysics, which combines ontological, noetic and theological doctrines, which brings Aristotle to the view that God is pure actuality, pure form without matter, a transcendent and perfect being or substance, an intellect that is an eternal thinking, the object of which is solely the thinking itself and which thus fulfils to the highest degree the idea of the identity of subject and object. And this self-related actuality of the divine intellect is at the same time the supreme and eternal life.

Against Ferrarin, who is particularly concerned with the relation of pure actuality in Aristotle and Hegel's conception of absolute subjectivity, we should not overlook that an important reason why Hegel sees his own philosophy as being in the tradition of Aristotle's theology is the fact that God, besides all the stated positive determinations, is also the highest truth $(\dot{\alpha} \lambda \dot{\eta} \theta \varepsilon 1 \alpha) .{ }^{11}$ In book $\alpha$ of the Metaphysics Aristotle explains:

that that which causes derivative truths to be true is most true. Therefore the principles of eternal things must be always most true; for they are not merely sometimes true, nor is there any cause of their being, but they themselves are the cause of the being of other things, so that as each thing is in respect of being, so it is in respect of truth. (Met. II, 1, 993b 26-31; Ross's translation)

A principle always has a higher degree of being and of truth than what is derived from it. Therefore philosophy does not only turn into theology when it is searching for the first principle of all beings; it is also, in as much as it is concerned with the first principle, a theory of truth ( $\theta \varepsilon \omega \rho i \alpha \pi \varepsilon \rho i$ in $\varsigma \dot{\alpha} \lambda \dot{\eta} \theta \varepsilon 1 \alpha \varsigma)$ in the sense of what is true being. True being and, therefore, the paragon of truth is God. And in relation to God a derived or ontologically dependent being always represents a lower degree of being as well as of truth. In Aristotle we find not only an ontological comparative which allows us to distinguish different degrees of being, but also a comparative with respect to truth. For Aristotle, a substance cannot only have a higher degree of being than an inferior substance but also, dependent on the degree of being, a substance also has a higher or lesser degree of truth. This is why, for example, God, as pure actuality, has the highest degree of being and truth. With respect to God, then, it is correct to say that he is the most true being of everything which exists.

For Aristotle, God is the paragon of truth. However, he wishes to say not only that God's thinking is always true, since there is no possibility of it erring, but that his thinking is, in itself, the highest truth or true being. That means for Aristotle that the thinking of the divine intellect is by itself the highest truth, insofar as it is, as the first substance, the first principle for all beings. Hence, Aristotle not 


\section{Tobias Dangel}

only affirms a mode of thinking that is always true, once it takes place-a thinking that is an understanding of the intelligible object and that belongs exclusively to the intellect or vov $\varsigma^{12}$ - but he also asserts the idea of a true being, which implies a concept of truth that is strictly ontological. When God is an eternal thinking of thinking, we must say that this thinking is, on the one hand, a thinking that is always true, because it is an intellectual intuition in which the thinking and the intellectual object are identical and, on the other hand, that this always-true thinking is the true being or the highest truth itself in the ontological sense. Both senses are obviously

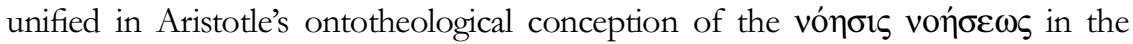
Metaphysics, which is why God is a substance the being of which is an intellectual intuition, or more precisely an intellectual self-intuition, so that the unity of the $\pi \rho \omega \tau \eta$

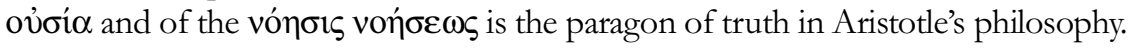

\section{Hegel's systematic integration of Aristotle's theology on the basis of his concept of truth}

It is this unity of both senses of truth in God that makes Aristotle's ontotheology highly relevant for Hegel's conception of the absolute idea and the absolute spirit, since Hegel, in confrontation with Kant's judgement-based conception of truth in the Critique of Pure Reason, tries to retrieve the ontological conception. In Hegel's view, such an ontological understanding allows us to distinguish between, on the one hand, truth as a property of judgement, which according to Hegel consists only in a formal coincidence of a subjective representation and an object-a coincidence which Hegel calls mere correctness (Richtigkeit). And, on the other hand, truth can also belong to the being or the object itself which means, then, an objective coincidence of a notion or an intelligible form with a being. Hegel calls such objective coincidence objective or material truth. ${ }^{13}$ He illustrates this distinction, which is of major importance for his entire system, in the Encyclopedia:

In common life the terms truth and correctness are often treated as synonymous: we speak of the truth of a content, when we are only thinking of its correctness. Correctness, generally speaking, concerns only the formal coincidence between our conception and its content, whatever the constitution of the content may be. Truth, on the contrary, lies in the coincidence of the object with itself, that is with the notion $[. .$.$] an immediate judgement$ in which an abstract quality is predicated of an immediately individual thing, however correct it may be, cannot contain truth. The subject and predicate of it do not stand to each other in the relation of reality and notion. (EL: \$172A, 237) 


\section{Hegel and Aristotle's Theology}

According to Hegel, the strength of the ontological or, in his terms, objective conception of truth which he finds, notably, in Aristotle's Metaphysics consists not least in the fact that it makes it possible to conceive the thinking of the absolute idea and of absolute spirit, which takes place when spirit thinks its own pure forms of thought, as an absolute or infinite realization of truth. Spirit is unrestrainedly 'with itself' when it thinks its notions so that the thinking of spirit must be regarded as an absolute self-coincidence-a self-coincidence that is realizable to the highest degree only for a being the structure of which is a conscious self-relation. Such a conscious self-relation takes place in spirit's thinking of itself. In this thinking notion and reality coincide unrestrainedly so that notion and reality are identical in the thinking of spirit.

The reason why spirit is unrestrainedly with itself when it thinks its own determinations is that these determinations that seem to have the status of intelligible objects are not separate from spirit, because they are spirit's internal determinations. The latter allows Hegel to speak of this spirit as absolute spirit. Spirit thinks its intelligible objects and at the same time produces them. Thus, when absolute spirit thinks intelligible objects, it is identical with them in the very actuality of its thinking. Absolute spirit and its determinations do not follow the opposition of subject and object but, on the contrary, spirit is identical with itself when it thinks these determinations. Due to this processual conception of the thinking of absolute spirit, Hegel can say that when it thinks its intelligible objects, this thinking is the realization of an unrestrained coincidence of the thinking and the object of thought, which is why the spirit thinks itself when it thinks its objects. In the thinking of absolute spirit, form and content, subjectivity and objectivity, or notion and reality, coincide and can be isolated only by the one-sidedness of the understanding's abstract thinking. However, if absolute spirit according to Hegel must be thought of as a structure or being that is self-related and in which spirit unrestrainedly coincides with itself, spirit's thinking is a productive activity in which spirit develops itself into the one concrete totality of forms of thought or determinations which are organically unified in a system of concepts. ${ }^{14}$ This organological system of concepts is in the end identical with the absolute idea or absolute spirit, so that the idea or spirit not only thinks the system of concepts but is this system itself. The thinking is the autonomous system of determinations and the autonomous system of determinations is thinking.

Following Hegel, absolute spirit is the totality of its determinations, being its parts or moments, while each moment is itself the presence of the totality, i.e., the presence of the unity of all moments. In this organological unity of the thinking of spirit, moment and totality mutually pervade one another, so that spirit is an infinite unity that possesses itself in all of its moments. Since absolute spirit's thinking is an unrestrained coincidence of form and content, subjectivity and objectivity, or notion and reality, which is possible only under the condition that absolute spirit 


\section{Tobias Dangel}

produces the totality of the forms by itself, it is spirit that can be regarded as the realization of the highest truth in the ontological sense. This is also why, for Hegel, self-thinking spirit is God or the fulfilled Absolute, because it is only the Absolute which we can think of as an unrestrained coincidence in which, especially, the opposition of finitude and infinity is sublated in favour of a true infinity that encompasses finitude and infinity as its moments. Therefore, Hegel explains in the Encyclopedia:

God alone is the thorough harmony of notion and reality. All finite things involve an untruth: they have a notion and an existence, but their existence does not meet the requirements of the notion. For this reason they must perish, and then the incompatibility between their notion and their existence becomes manifest. It is in this kind that the individual animal has its notion; and the kind liberates itself from this individuality by death. (EL: $\$ 24 \mathrm{~A} 2,41)$

When Hegel ends his Encyclopedia with a reference to Aristotle's theology, it is obvi-

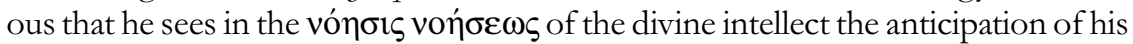
conception of a fulfilled objective truth that is identical with the absolute idea or absolute spirit. Since we find in chapter 9 of book $\Lambda$ the argument that for the sake of God's perfection the thinking of the divine intellect can only be a thinking that is directed towards itself, in Hegel's interpretation it was Aristotle who first articulated that the highest being is at the same time the highest truth and the divine intellect's thinking of itself. For Hegel this means that Aristotle was the first to have the right concept of God or the Absolute. ${ }^{15}$

To better understand what Hegel expects to find in Aristotle's ontology as well as in his theology, we can say that for Hegel it was Aristotle who developed a concept of God in which substantiality and subjectivity, or notion and reality, are identical. For, as we have seen, it is part of Aristotle's conception of God that God's being is his thinking and that vice versa God's thinking is his being, so that being and thinking cannot be separated in God. Another aspect of Aristotle's conception of God is that he is not only the identity of being and thinking, but that his thinking is also absolutely self-related. The fact that, for Aristotle, God is unrestrainedly for himself implies that God's being is unrestainedly selftransparent, too. So when God is pure actuality, because there is no potentialitythat is to say, no matter-in God, pure actuality must be understood as a form ( $\tilde{\varepsilon} \tilde{i} \delta o \varsigma)$ which is for itself, and God's self-thinking thinking is this form. In other words: God can be the highest truth only because he is, as pure actuality,

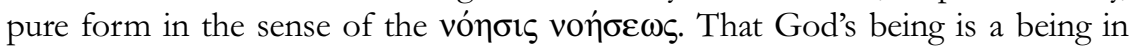
which the intellect is unrestrainedly for itself is the reason why Hegel can say that God in Aristotle's theology is an infinite self-consciousness and an infinite 


\section{Hegel and Aristotle's Theology}

subjectivity, in which the opposition of subject and object is sublated so that subject and object have become moments of the concrete unity that the infinite subjectivity is. Hegel emphasizes this in his Lectures on the History of Philosophy, where he states in the chapter on Aristotle's metaphysics:

The highest point is, however, that in which potentiality, activity and actuality are united; the absolute substance, the true, the in-and-for-itself which Aristotle (XII, 6, 7; IX, 8) defines in general as being the unmoved, the unmovable and the eternal which yet at the same time moves, is pure activity, actus purus. [...] If in later times it has seemed something new to define absolute essence as pure activity, we see that this arises from a lack of knowledge of the Aristotelian conception. But the Scholastics rightly looked upon this as the definition of God: God is pure activity, that which is in and for itself; he does not require anything material - there is no higher idealism. (TWA: 19: 158; my trans.)

And at a later passage Hegel says with reference to Aristotle:

It is only in thought that there is present a true coincidence between objective and subjective; that am I. Aristotle therefore finds himself at the highest standpoint; one can desire to know nothing deeper [...]. (TWA: 19: 165; my trans.)

God's actuality, which is 'the true' in which subjectivity and objectivity are unified and which is as the thinking of thinking an intellectual intuition, is in Hegel's reading the essence of the I. God's self-thinking thinking is the fundament of the subjectivity by which I am self-conscious. In Hegel's view, Aristotle knows that in the self-consciousness of the human intellect the intellect is not separated from the divine intellect, so that self-consciousness is the place where the human intellect and the divine intellect are identical. ${ }^{16}$ While Aristotle conceptualizes God as a selfrelated thinking in which the divine intellect is unrestrainedly self-conscious and is thus 'the true' as the coincidence of subjectivity and objectivity, self-consciousness and the I are a higher realization of truth than all representations and judgements that can be accompanied by the 'I think', as Kant stated in Critique of Pure Reason \$16. The fact that, for Aristotle, the intellect when it thinks becomes identical with its object, so that God is the eternally fulfilled coincidence of subjectivity and objectivity and thus the highest truth, is the reason why Hegel sees the highest idealistic standpoint realized in Aristotle's theology. ${ }^{17}$ In the Science of Logic, Hegel refers implicitly to this Aristotelian standpoint as a basis for a critique of Kant's 'I think' and the concept of truth within the realm of his transcendental idealism. 


\section{Tobias Dangel}

When Kant, in connection with logic comes to discuss the old and famous question; what is truth? he first of all presents to the reader as a triviality the explanation of the term as the agreement of cognition with its object-a definition of great, indeed of supreme, value. If we remember this definition in connection with the fundamental assertion of transcendental idealism, that reason as cognitive is incapable of apprehending things-in-themselves, that reality lies absolutely outside the Notion, then it is at once evident that reason such as this which is unable to put itself in agreement with its object, the things-in-themselves, and things-in-themselves that are not in agreement with the Notion of reason, the Notion that is not in agreement with reality, and a reality that does not agree with the Notion, are untrue conceptions. If Kant had considered the Idea of an intuitive understanding in the light of the above definition of truth, he would have treated that Idea which expresses the required agreement, not as a figment of thought but rather as the truth. (WL: 593)

The Idea of an 'intuitive understanding' satisfies the concept of truth when truth is the agreement of subjectivity and objectivity or of the notion and reality. And, as we have already seen, it is this agreement which according to Aristotle is God, since God's being is a thinking which thinks itself. For Hegel, it was Aristotle who anticipated the infinite subjectivity of the notion or the absolute idea when he concep-

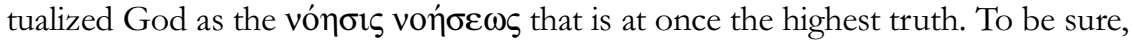
Kant had achieved a high standpoint when he argued that the transcendental unity of self-consciousness is the basis of the unity of judgement as well as of the unity of our intuition. But for Hegel, Kant's 'I think', although a transcendental principle of unity, remains formal and empty, and thus a notionless conception, which Hegel confronts in the Science of Logic in particular with Aristotle's conception of an intellect which is in the activity of thinking identical with its object and which is at its

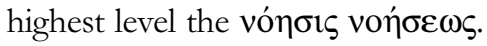

Now a notionless concept of this kind [i.e. Kant's 'I', T.D.] may indeed oppose itself to the abstract reflective determinations or categories of the previous metaphysics: for in one-sidedness it stands on a level with them, though these are indeed on a higher level of thought; but on the other hand it appears all the more meagre and empty when compared with the profounder ideas of ancient philosophy on the conception of the soul or of thinking, as for example the genuinely speculative ideas of Aristotle. If the Kantian philosophy investigated the reflective categories in question, it was even more bound to investigate the firmly 


\section{Hegel and Aristotle's Theology}

held abstraction of the empty ' $\mathrm{I}$ ', the presumed idea of the thing-in-itself, which, precisely on account of its abstraction, proves on the contrary to be something completely untrue. (WL: 778-79)

\section{A critical outlook}

Now we have reached the point to ask where the main difference between Aristotle's theology and Hegel's conception of the absolute idea or absolute spirit can be recognized. In my view, we find this difference in Aristotle's and Hegel's understanding of the activity of God or the Absolute. As we have already seen,

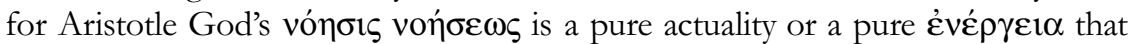
is free from all potentiality, that is free from matter and thus pure form. The

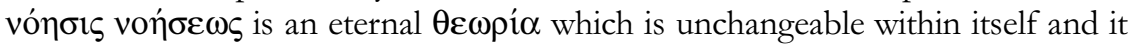
is eternal activity in the sense of a self-related intellectual intuition, the object of which consists of nothing else other than God's own intellectual intuition. In this intuition, which is for Aristotle the highest realization of truth, there can be no processuality. In other words: God's thinking is the unchangeable positivity or presence of being itself which is for itself in the way of a self-related intellection.

For Hegel, however, as he shows in the Doctrine of the Notion in the third part of the Science of Logic, the activity of the notion is an operation of a negativity which only refers to negativity itself. ${ }^{18}$ Hegel calls this self-related negativity the activity of the notion (die Tätigkeit des Begriffs), which is the articulation of what for Hegel is infinite subjectivity. Without going into details here, Hegel's conception of an absolute or self-related negativity must be regarded as an autonomous or free process in which the immediate notion differentiates itself within itself into two opposing moments. But nevertheless the notion is identical with itself in these moments, since in them the notion at once is returning to itself, into its primary unity, which is now a mediated unity or a concrete totality of the moments of the notion. According to Hegel, the notion's diremption is a processual selfmediation to a higher and richer unity of the notion. The higher unity or the highertier notion is mediated or reflected in itself and is always a form of thought that is (in the end) a more fulfilled concretization of the absolute idea.

When Hegel, in the Lectures on the History of Philosophy, as well as in the Science of Logic and the Encyclopedia, explicitly sees an anticipation of his infinite subjectivity

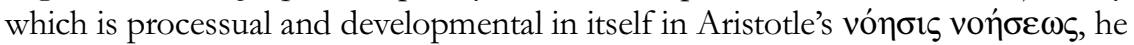
connects the latter with his own conception of the notion's self-related negativity, which is obviously incompatible with Aristotle's idea of the pure positivity or pres-

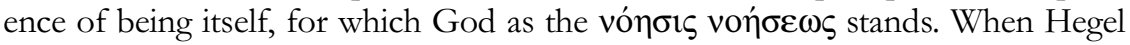
tries to convince us that he returns to Aristotle's theology with his theory of the 


\section{Tobias Dangel}

absolute idea and the absolute spirit, this is convincing only insofar as Hegel can really find a theory of a first being in the Metaphysics, in which substantiality, selfthinking thinking and the highest ontological truth are unified in God. But Hegel gives Aristotle's theology too much of a Neoplatonic appearance when he

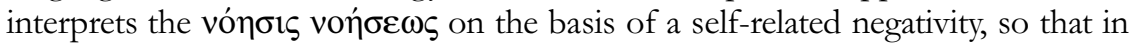
Hegel's reading God's thinking becomes a process in which God unfolds himself into a plurality of forms or concepts. There is no evidence in book $\Lambda$ of the Metaphysics that Aristotle regards the activity or actuality of God's self-thinking thinking as productive in itself. Insofar as such an interpretation is much more Neoplatonic than originally Aristotelian, one might maintain that Hegel's conception of the absolute idea and absolute spirit, which contains the process of God's self-unfolding as the process of the infinite subjectivity of the notion, is more compatible with philosophies such as that of Plotinus or Proclus than with Aristotle's. And this, I would say, is correct, even though Hegel rejects in his philosophical system the Neoplatonic theory of absolute Oneness—a Oneness that, because of its

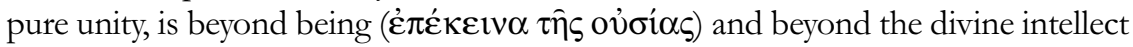

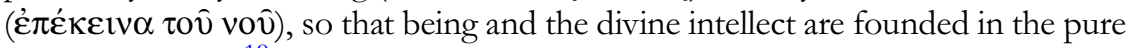
unity of the One. ${ }^{19}$

\section{Tobias Dangel \\ University of Heidelberg, Germany dangel@uni-heidelberg.de}

\section{Notes}

\footnotetext{
${ }^{1}$ See also Pinkard, who highlights the relevance of Aristotle's thoughts for Hegel: 'By his own account, Hegel takes his views on Aristotle to have shaped his entire thinking about how best to conceptualize our own status as creatures with minds and how to think about the role that practical reason plays in human life' (2012: 17).

2 Abbreviations used:
}

$L P R=$ Hegel, Lectures on the Philosophy of Religion, vol. 1, trans. E. B. Speirs and J. Burdon Sanderson. New York: Humanities Press, 1962. $W L=$ Hegel, Hegel's Science of Logic, trans A. V. Miller. London: Allen \& Unwin, 1969.

TWA = Hegel, Werke in Zwanzig Bänden. Theorie-Werkausgabe, eds. E. Moldenhauer and K. M. Michel. Frankfurt: Suhrkamp, 1969. $E L=$ Hegel, Hegel's Logic, trans. W. Wallace. Oxford: Clarendon Press, 1975. 


\section{Hegel and Aristotle's Theology}

3 The relation between Hegelian and Aristotelian metaphysics has increasingly concerned Hegel scholars for some years now. There are contributions of different relevance and impact. In my view the most important are Düsing (1983), (1997) and (2004), De Koninck (1994), Ferrarin (2001), and Dangel (2013). Furthermore, see De Laurentiis (2018), German (2018), Mendelsohn (2018) and Halfwassen (2019).

${ }^{4}$ For the reconstruction of Aristotle's proof, see Dangel (2013: 67-99). A thorough interpretation and discussion of book Lambda as a whole, which is concerned with all aspects of this book, can be found in Frede and Charles (2000).

${ }^{5}$ I follow Elders, who states: 'In Phys. III the term $\mu \varepsilon \tau \alpha \beta \beta \lambda \dot{\eta}$ is used to signify change in general, including generation and destruction, growth and diminution and also locomotion. It is largely

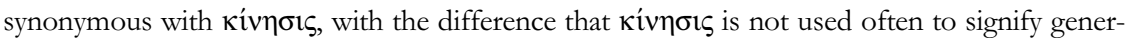
ation and corruption' (1972: 88).

${ }^{6}$ Lear gives a good characterization of how Aristotle relates the world to God: '[God, T.D.] has no purposes or intentions: so the teleological organization to be found in the world manifests a rational order for which God is responsible, even though he did not plan the world, even though the world is not working out God's purposes. God is the final cause: the order depends on him. The order of this well-ordered world must be in some relation to God if he is to be responsible for it. [...] Then we can see the world as a whole as dependent on God: for the realization of form in the natural world depends upon the antecedent existence of form at its highest-level actuality. But form or primary substance at its highest-level actuality simply is God. And the desire which God inspires is none other than the desire of each organism to realize its form. Each natural organism has within it a desire to do those things necessary to realizing and maintaining its form' (1988: 295).

7 Three main interpretations of what Aristotle's God thinks can be distinguished. (1) God's thinking is a thinking of all substantial forms, i.e., in God's intellect all $\varepsilon$ « $\delta \eta$ have actuality, so that God's intellect is the actual totality of all forms in which God thinks himself. This interpretation can be found in, e.g., Thomas Aquinas' In Metaphysicam Aristotelis Commentaria: lib. XII, lect. XI, n. 2614. Such a Thomistic interpretation is found prominently in Burnyeat (2008). The second main interpretation (2) understands God's thinking as a thinking in which God thinks only himself, i.e., God does not think himself in different forms but only in the actuality of

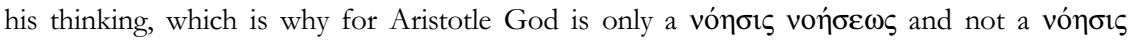

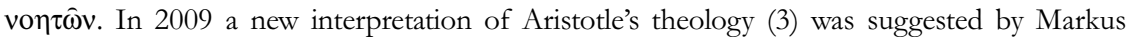
Gabriel. He argues that God's being must not be understood as thinking at all, for in

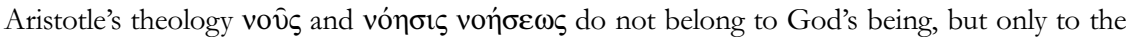

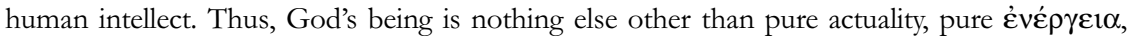

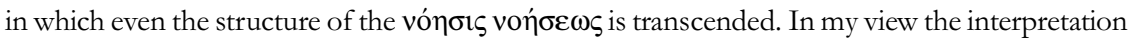
which fits best the text of chapter 7 and 9 of book Lambda is the second one-an interpretation that was first offered by Klaus Oehler $(1974,1984)$.

8 This is also suggested by Eth. Eud. VII, 12, 1245b 14-19.

9 'Now the object of knowledge makes a difference to the value of the knowledge; the object of the supreme reason must therefore be what is most divine, and therefore not different things in 


\section{Tobias Dangel}

different times. Any change must be a change for the worse, and, apart from this, no change should be ascribed to that which has been shown in ch. 7 to be the unchangeable' (Ross 1924: 397).

10 'God, by contrast, requires no interaction with anything external to be in his active state. Since in his case as well subject and object of thought are identical, there is no objection to saying that he thinks himself. Further, we can characterize his activity as a thinking of thinking, rather than as a thinking of essences in the world' (Lear 1988: 301).

11 The fact that for Aristotle God is the highest truth, and that this conception is most relevant for Hegel's reception of Aristotle's theology, is largely ignored by Ferrarin (2001).

12 That the thinking of vov̧ must be understood as an intellectual intuition which must be distinguished from the discursivity of $\delta$ ióvoro is the subject of Met. IX, 10, 1051b 30-1052a 4. See also An. post. II, 19, 100b 11-15, where Aristotle states that the principle of knowledge

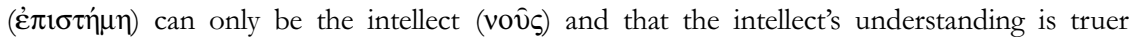

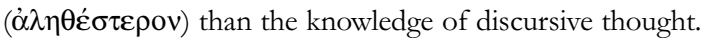

13 On Hegel's ontological conception of truth, see the analyses of Stern (1993), Halbig (2002: 185-90) and Dangel (2013: 243-76).

14 This approach is quite close to the Platonic teaching of God as the intellectual cosmos of the ideas in Rep. 500b 8-c. In Tim. 30c 3-31b 4 Plato regards God or the demiurge as a living being ( $(\tilde{\omega} \mathrm{ov})$ whose thoughts are living beings $(\zeta \tilde{\omega} \alpha)$ as well, which implies that for Plato God is an intellectual cosmos the unity of which is a living or organological unity.

${ }^{15}$ A helpful synoptic view of this aspect can be found in Halfwassen (2019).

${ }^{16}$ Ferrarin is correct that: '[...] for Hegel Aristotle's human nous thinks itself and is thereby the actualization of divine nous' (2001: 126). See also Burnyeat (2008). It seems to me that it is this what Pinkard alludes to by emphazising: 'Hegel's point is, rather, Aristotelian (or at least follows the Aristotelianism of the end of the Nicomachean Ethics) in one obvious way: The final end is for Hegel, as it was for Aristotle, something like contemplation, and, as it is for Aristotle, it is characterized by Hegel as divine' (2012: 108). For Hegel the human intellect can become identical with the divine intellect when it thinks God, so that God's self-thinking thinking and our thinking of God cannot be separated but are identical. This is unmistakably expressed when Hegel invokes Meister Eckhart as a witness for his concept of absolute spirit in the Lectures on the

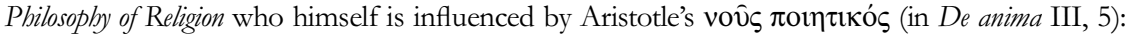
'Meister Eckardt, a Dominican monk, in speaking of this innermost element, says, in one of his sermons, among other things, the following: "The eye with which God sees me is the eye with which I see Him; my eye and His eye are one. By righteous standard I am weighed in God, and God in me. If God were not, I would not be; if I were not, then He were not. It is, however, not needful to know this, for there are things which are easily misunderstood and which can only be thoroughly understood in thought"” (LPR 217).

17 This is why I cannot follow Pippin (1989: 5) when he advocates a Kantian interpretation of Hegel, on which Hegel's speculative position, basically his theory of the Absolute Idea, his claim that such an Idea alone is "what truly is", can be interpreted and defended in a way that is not committed to a philosophically problematic theological metaphysics. 


\section{Hegel and Aristotle's Theology}

${ }^{18}$ For a detailed discussion of Hegel's conception of a self-related negativity, of which the notion's infinite subjectivity consists, see Koch (1999) and Dangel (2013: 277-94).

19 The most detailed reconstruction of Hegel's interpretation and systematic analysis of Neoplatonic metaphysics is given by Halfwassen (1999). With regard to Plotinus's conception of the One and its absolute transcendence, see Halfwassen (2014).

\section{Bibliography}

Aquinas, T. (1926), In Metaphysicam Aristotelis Commentaria, ed. M.-R. Cathala. Rome: Taurini Marietti.

Aristotle (1950), Physica, recognovit brevique adnotatione critica instruxit W. D. Ross. Oxford: Oxford University Press.

Aristotle (1956), De anima, recognovit brevique adnotatione critica instruxit W. D. Ross. Oxford: Oxford University Press.

Aristotle (1957), Metaphysica, recognovit brevique adnotatione critica instruxit W. Jaeger. Oxford: Oxford University Press.

Aristotle (1984), The Complete Works of Aristotle. The Revised Oxford Translation, 2 vols., ed. J. Barnes. Princeton: Princeton University Press.

Aristotle (1991), Ethica Eudemia, recensuerunt brevique adnotatione critica instruxerunt R. R. Walzer, J. M. Mingay, prefatione auxit J. M. Mingay. New York: Oxford University Press.

Burnyeat, M. F. (2008), Aristotle's Divine Intellect. The Aquinas Lecture 2008. Milwaukee: Marquette University Press.

Dangel, T. (2013), Hegel und die Geistmetaphysik des Aristoteles. Berlin: De Gruyter.

De Koninck, T. (1994), 'Aristotle on God as Thought Thinking Itself', Review of Metaphysics 47: 471-515.

De Laurentiis, A. (2018), 'The Aristotelian Metaphysics of Hegel's "Soul'”, in G. A. Magee (ed.), Hegel and Ancient Philosophy. A Re-Examination. New York: Routledge.

Düsing, K. (1983), Hegel und die Geschichte der Philosophie. Darmstadt: Wissenschaftliche Buchgesellschaft.

Düsing, K. (1997), 'Ontologie bei Hegel und Aristoteles', Hegel-Studien 32: 61-92. Düsing, K. (2004), 'Noesis Noeseos und absoluter Geist in Hegels Bestimmung der "Philosophie", in Lucas, Tuschling and Vogel (eds.), Hegels enzy/klopädisches System der Philosophie. Von der Wissenschaft der Logik zur Philosophie des absoluten Geistes. Stuttgart-Bad Cannstatt: Frommann-Holzboog.

Elders, L. (1972), Aristotle's Theology. A Commentary on Book $\Lambda$ of the Metaphysics. Assen: Royal Van Gorcum.

Ferrarin, A. (2001), Hegel and Aristotle. Cambridge: Cambridge University Press. 


\section{Tobias Dangel}

Frede, M. and Charles, D. (eds.) (2000), Aristotle's Metaphysics Lambda. Symposium Aristotelicum. Oxford: Oxford University Press.

Gabriel, M. (2009), 'God's Transcendent Activity-Ontotheology in Metaphysics $\Lambda$ ', Review of Metaphysics 63: 385-414.

German, A. (2018), 'Mens Divina as Lebendigkeit: Hegel's Interpretation of Metaphysics 1072b26-27', in G. A. Magee (ed.), Hegel and Ancient Philosophy. A Re-Examination. New York: Routledge.

Halfwassen, J. (1999), Hegel und der spätanike Neuplatonismus. Untersucbungen zur Metaphysike des Einen und des Nous in Hegels spekulativer und geschichtlicher Deutung. Bonn: Bouvier.

Halfwassen, J. (2014), 'The metaphysics of the One', in P. Remes and S. Slaveva-Griffin (eds.), The Routledge Handbook of Neoplatonism. New York: Routledge.

Halfwassen, J. (2019), 'Hegel's Programmatic Recourse to the Ancient Philosophy of Intellect', in S. Gersh (ed.), Plotinus's Legacy: The Transformation of Platonism from the Renaissance to the Modern Era. Cambridge: Cambridge University Press.

Halbig, C. (2002), Objektives Denken. Erkenntnistheorie und Philosophy of Mind in Hegels System. Stuttgart-Bad Cannstatt: Frommann-Holzboog.

Koch, A. F. (1999), 'Die Selbstbeziehung der Negation in Hegels Logik', Zeitschrift für philosophische Forschung 53:1-29.

Lear, J. (1988), Aristotle: The Desire to Understand. Cambridge: Cambridge University Press.

Mendelsohn, J. (2018), 'The Way Past the Stripping Argument in Hegel and Aristotle', in G. A. Magee (ed.), Hegel and Ancient Pbilosophy. A Re-Examination. London: Routledge.

Oehler, K. (1974), 'Aristotle on Self-Knowledge', Proceedings of the American Philosophical Society 118: 493-506.

Oehler, K. (1984), 'Der höchste Punkt der antiken Philosophie', in K. Oehler, Der Unbewegte Beweger des Aristoteles. Frankfurt: Klostemann.

Pinkard, T. (2012), Hegel's Naturalism. Mind, Nature, and the Final Ends of Life. New York: Oxford University Press.

Pippin, R. (1989), Hegel's Idealism. The Satisfaction of Self-Consciousness. Cambridge: Cambridge University Press.

Plato (1901-07), Platonis Opera, 5 vols., recognovit brevique adnotatione ctritica instruxit I. Burnet. Oxford: Clarendon Press.

Ross, W. D. (1924), Aristotle's Metaphysics. A Revised Text with Introduction and Commentary, 2 vols. Oxford: Clarendon Press.

Stern, R. (1993), 'Did Hegel Hold an Identity Theory of Truth?', Mind 102: 645-47. 